\title{
Municipal waste water toxicity evaluation with Vibrio fisheri
}

\author{
Helena Raclavska, Jarmila Drozdova, Silvie Hartmann \\ Energy Units for Utilization of non Traditional Energy Sources (ENET) \\ VŠB-Technical University of Ostrava \\ Ostrava, Czech Republic \\ jarmila.drozdova@vsb.cz
}

Received: January 28, 2021 Revised: February 25, 2021. Accepted: March 10, 2021. Published: March 24, 2021.

\begin{abstract}
Toxicity of municipal waste water observed by means of Vibrio fischeri proved a primary dependence between the content of organics and inhibition. A linear dependence between COD and inhibition determined by means of Vibrio fischeri was established. In 30 days following sampling organic matter was degraded and the value of inhibition fell from $80 \%$ to $27.67 \%$. This value corresponds to the real impact of micropollutants (risk elements, organic micropollutants) on inhibition. The content of risk elements in municipal waste water implies that the values are significantly higher than $\mathbf{E C}_{50}$ defined for Daphnia magna. Risk element ecotoxicity is affected by the form of occurrence and it is thus probable that there are risk elements predominantly in the form of complexes in sewage water.
\end{abstract}

Keywords-Vibrio fischeri; ecotoxicity; COD (chemical oxygen demand); BOD (biochemical oxygen demand); risk elements

\section{INTRODUCTION}

The requirements for the quality of discharged water from municipal waste water treatment plants (WWTPs) have been considerably tightened within the European Water Framework Directive (Directive 2000/60/EC), which, apart from chemical parameters, defines an environmental quality aspect [1]. Ecotoxicity monitoring may significantly contribute to the evaluation of discharged water quality $[2,3,4]$. Waste water ecotoxicity may be greatly influenced by risk elements, organic micropollutants and other factors (turbidity, increased content of nutrients, etc.). Knowledge of the species of metals is important in removing elements in the framework of WWTPs technology but also from potential ecotoxicity of sludges and water discharge from WWTPs [5]. Some elements (B, Mn, Co, $\mathrm{Ni}$ and $\mathrm{Mo}$ ) are difficult to treat in WWTPs, $60-80 \%$ are discharged with treated water [6]. $\mathrm{Pb}, \mathrm{V}, \mathrm{Cu}, \mathrm{Ag}, \mathrm{Cd}, \mathrm{Sb}$ and $\mathrm{Ba}$ are concentrated mainly in sewage sludge and (As and $\mathrm{Zn}$ ) can occur in treated water or sewage sludge. The removal of $\mathrm{Cr}, \mathrm{Cu}, \mathrm{Pb}$ and $\mathrm{Fe}$ is likely to be strongly linked to the removal of suspended solids. $\mathrm{Cd}$ and $\mathrm{Ni}$ compounds are most often dissolved (86 \% and $78 \%$, respectively) [7]. Detailed information regarding the speciation of heavy metals in urban sewers is lacking [8].

The objective of the paper is to identify variability in municipal waste water ecotoxicity in the individual districts of the City of Ostrava and to assess the impact of meteorological conditions.

\section{METHODS}

The waste water toxicity was determined in accordance with the EN ISO 11348 Standard, which defines the inhibition effects of water samples on light emission by Vibrio fischeri (luminescent bacteria test). The use of the method is limited by interfering phenomena - loss of luminescence caused by absorption or diffusion of light in heavily-coloured or turbid samples or the presence of organic, well biodegradable nutrients (urea, peptone, yeast extract $>100 \mathrm{mg} / \mathrm{L}$ ), which may cause a reduction in bioluminescence independently on the pollutants.

The observation of inhibition of Vibrio fischeri was conducted with 60 samples of municipal waste water drawn from 13 sampling points of the sewerage system of the City of Ostrava (OVAK, a.s.). Once a month samples were drawn in the sampling points stated in Fig. 1. Significant hydrochemical markers (BOD, COD, TOC, major anions and cations, risk elements and toxicity) were determined in the waste water samples. The determination of toxicity was repeated in 30 days after sampling, having kept the samples in a refrigerator at the temperature of $4^{\circ} \mathrm{C}$ (60 samples).

\section{ORGANIC POLLUTION IMPACT ON THE INHIBITION OF VIBRIO FISHERI}

Studying the relations between inhibition and chemical parameters observed in municipal water, we identified a statistically important dependence between inhibition and BOD, COD, TOC, phosphates, total nitrogen and turbidity (Fig. 2 and 3). The dependence between inhibition of Vibrio fischeri and BOD, COD and the content of undissolved substances is also reported by [9] and [10].

Fig. 4 shows the median values for the inhibition of Vibrio fischeri. The position of the sampling points in the Fig. 4 corresponds to their location in the sewerage system with regard to their potential mutual influence. The lowest inhibition was identified in the Polanka, Svinovsky and Vratimovsky collectors; the inhibition determined in the three collectors may be considered as background values for immediate sampling. 


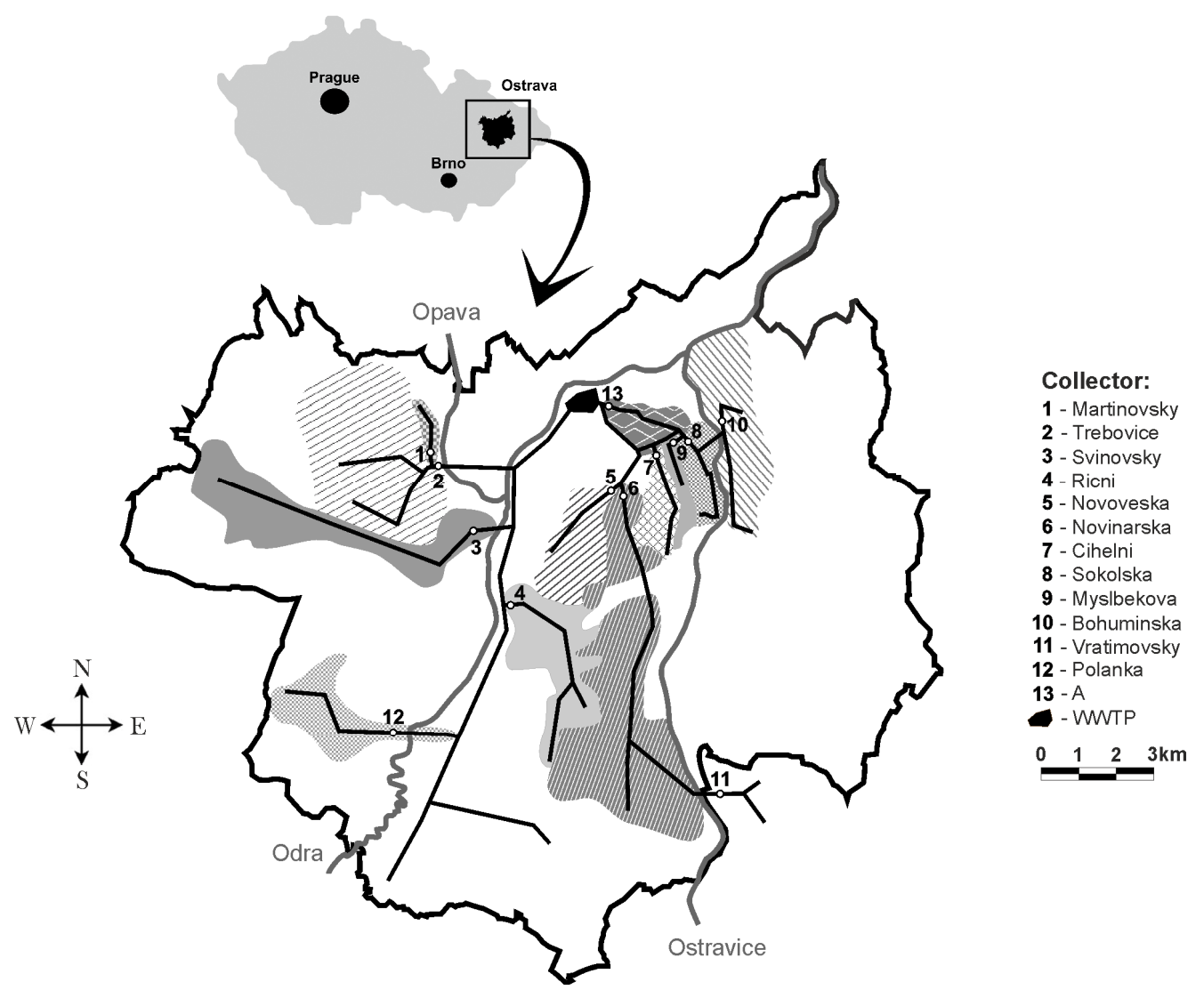

Fig. 1. Catchments of individual collectors and locations of sampling points

The Polanka collector shows the lowest median value for COD (170 mg/L) and in Svinovsky collector it is $185.7 \mathrm{mg} / \mathrm{L}$, while the complete set median is $357 \mathrm{mg} / \mathrm{L}$. Fig. 1 reveals a mutual influence of some sampling points: Vratimovsky collector (beginning of collector) and Novinarska collector (end of collector), Bohuminska collector and Sokolska collector.

It is apparent from the dependence of the organic pollution impact on inhibition (Fig. 2 and 3 ) that the inhibition will decrease in waste water along with the removal of organics, all the way to the value expressing the inhibition caused by the presence of pollutants (risk elements, organic micropollutants). Fig. 4 documents a drop in inhibition values. The inhibition median for the complete set of waste water in the day of

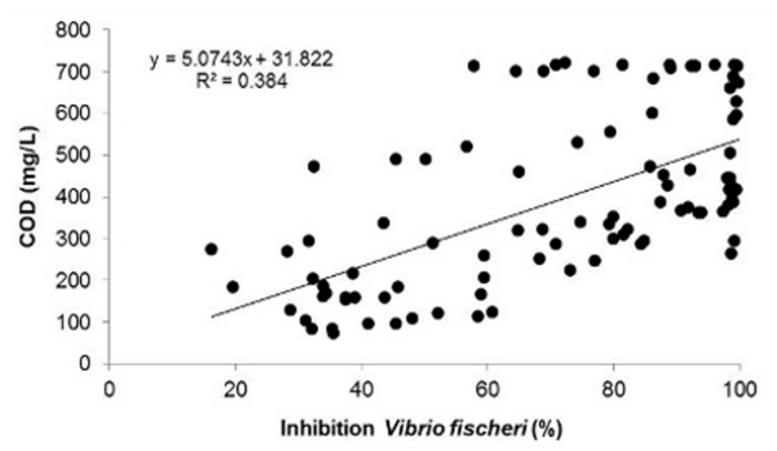

Fig. 2. Dependence between COD and inhibition sampling is $79.58 \%$; the inhibition median after 30 days is $27.67 \%$.

The decrease in inhibition after 30 days was identified in all the samples, except for the Martinovsky collector (Fig. 5 and 6). Apart from sewage, waste water from the food-processing industry and metallization is discharged into the Martinovsky collector.

In this case probably the risk elements, which formed complexes with organics at the instant of sampling, transformed into an ion form after the degradation of organics, which causes toxicity. The Martinovsky collector demonstrates the highest content of $\mathrm{Zn}$, the median value is $450 \mathrm{mg} / \mathrm{L}$; in other collectors the $\mathrm{Zn}$ contents ranged from 120 to $210 \mathrm{mg} / \mathrm{L}$.

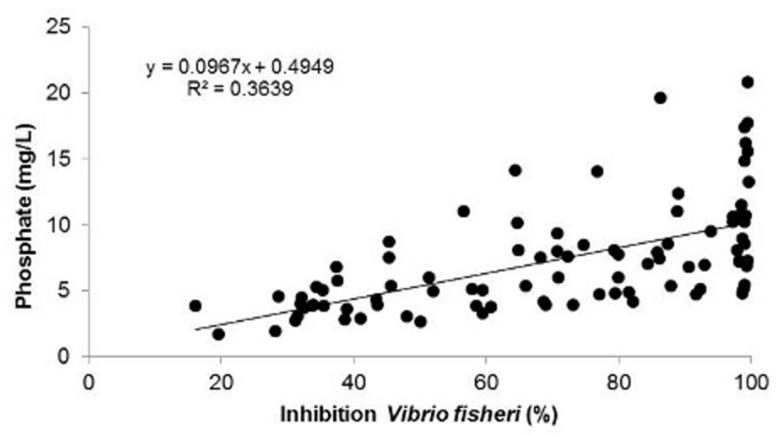

Fig. 3. Dependence between phosphates and inhibition 


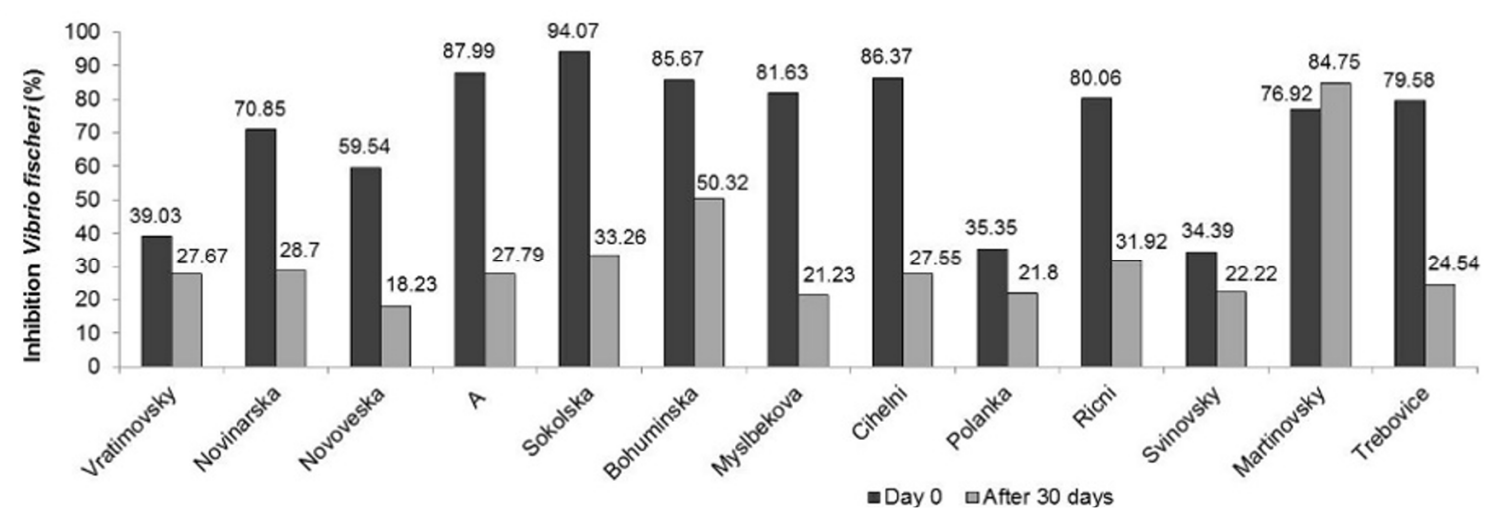

Fig. 4. Median of inhibition values (120 samples) in the sampling day; median of inhibition values after 30 days (60 samples)

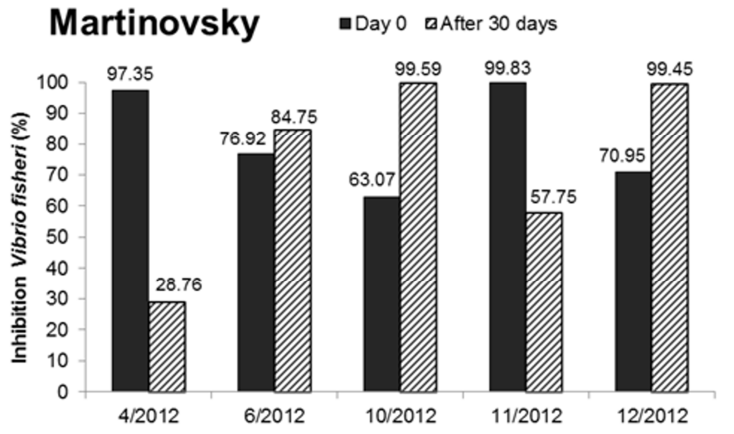

Fig. 5. Inhibition determined in the sampling day and after 30 days Martinovsky collector

Fig. 7 reveals that in all collectors the lowest inhibition was measured in May and November. Considering the fact the inhibition value is influenced by the presence of organics (BOD, COD). It may be presumed that the reduction in inhibition is caused by dilution of the organic pollution in the collectors due to higher rain fall. Fig. 8 states the volume of the inflowing water into the WWTP in the days of sampling. The quantity of inflowing water in May and November was the highest during the observed period.

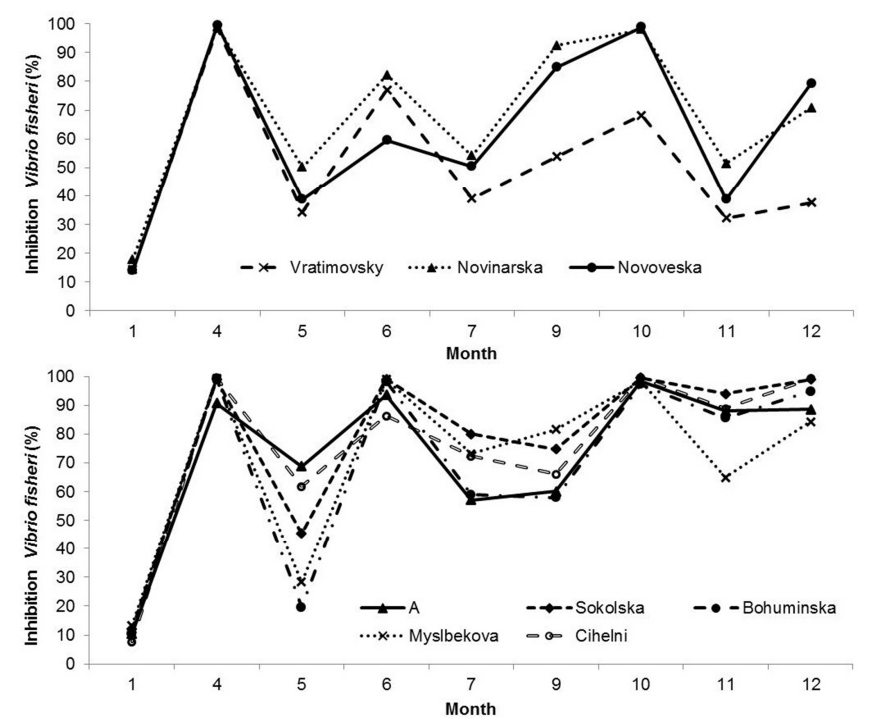

Fig. 7. Inhibition values in dependence on the sampling times

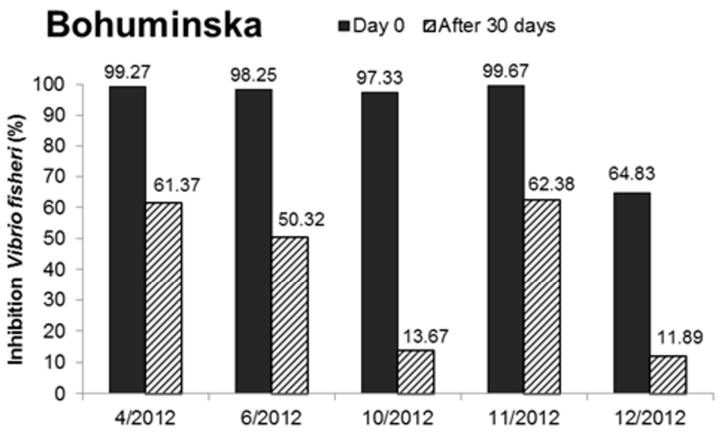

Fig. 6. Inhibition determined in the sampling day and after 30 days Bohuminska collector

It is apparent from the results that organic pollution participates in the high value of inhibition of Vibrio fischeri. After degradation of organics during 30 days the inhibition drops to a value which corresponds to the impact of micropollutants on ecotoxicity.
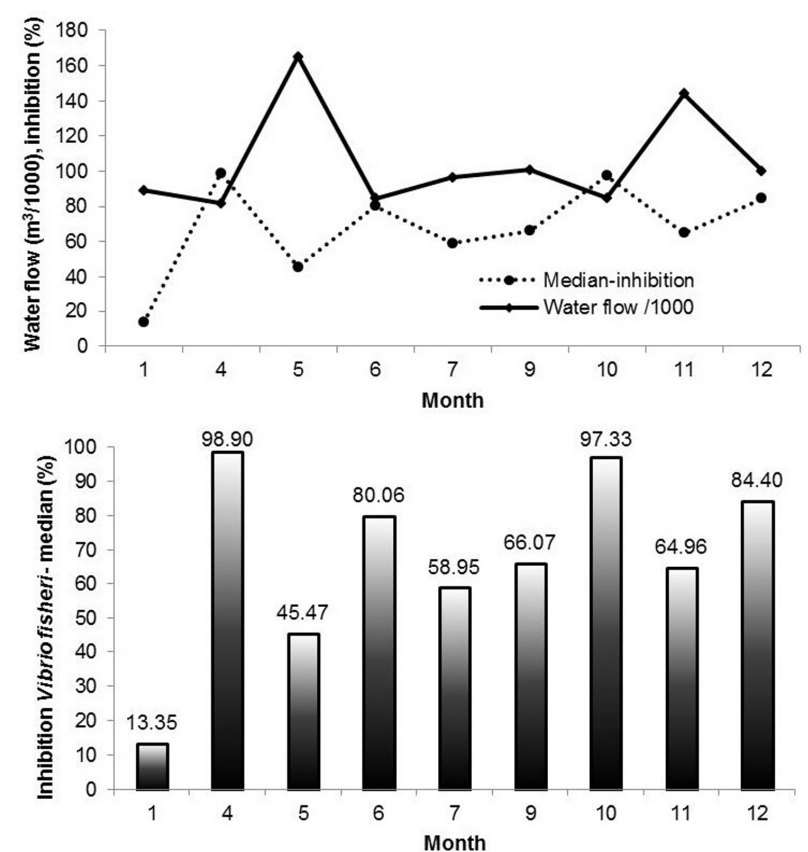

Fig. 8. Inhibition values - median compared with the quantity of inflowing water into a WWTP 
TABLE I. MEDIAN OF THE OBSERVED ELEMENT CONTENTS IN THE COLLECTORS COMPARED WITH THE POLANKA COLLECTOR

\begin{tabular}{|c|c|c|c|c|c|c|c|c|c|c|}
\hline & As & Cd & $\mathbf{C u}$ & $\mathrm{Cr}$ & $\mathbf{F e}$ & $\mathrm{Hg}$ & Mn & $\mathbf{P b}$ & $\mathbf{V}$ & $\mathrm{Zn}$ \\
\hline & \multicolumn{10}{|c|}{$(m g / L)$} \\
\hline Polanka & 3.10 & 0.14 & 27.2 & 11.9 & 320 & 0.30 & 190 & 47 & 9.45 & 98 \\
\hline Complete set & 3.33 & 0.24 & 34.16 & 11.6 & 452 & 0.33 & 189 & 66 & 5.16 & 210 \\
\hline TRV $^{\mathrm{a}}$ & 0.19 & & 0.06 & 0.12 & 1.0 & 0.00001 & & 0.0013 & 0.020 & 0.120 \\
\hline $\operatorname{LOEC}(\mu \mathrm{g} / \mathrm{L})^{\mathrm{b}}$ & & & $6.78-13.6$ & & & & & $62.6-1251$ & & \\
\hline $\mathrm{EC}_{50}(\mathrm{mg} / \mathrm{L})^{\mathrm{c}}$ & & 0.11 & & 0.117 & & & & & & \\
\hline
\end{tabular}

a. Toxicity reference value [15].

Table I states the contents of observed risk elements for the Polanka collector, which showed the lowest inhibition in the samples analyzed in the day of sampling and the median of the complete set. Compared with the ecotoxicity limits according to TRV (Toxicity Reference Value), which were observed in Daphnia magna, the values of element contents in the municipal water are significantly higher. Also the values of LOEC (Lowest Observable Effect Concentration) for $\mathrm{Cu}$ and $\mathrm{Cr}$ reported by [11] are lower by as much as three orders. The toxic contribution of the individual elements was defined by [12]. EC20 values for Vibrio fischeri, which represent a measurable thresholds of toxicity were found to form following series: $\mathrm{Pb}(\mathrm{II})>\mathrm{Ag}(\mathrm{I})>\mathrm{Hg}(\mathrm{II}) \approx \mathrm{Cu}(\mathrm{II})>\mathrm{Zn}(\mathrm{II})>\mathrm{As}(\mathrm{V})>$ $\mathrm{Cd}(\mathrm{II}) \approx \mathrm{Co}(\mathrm{II})>\mathrm{As}(\mathrm{III})>\mathrm{Cr}(\mathrm{VI})$. The presence of humic acids in the municipal waste water may significantly influence the toxicity of risk elements through the formation of complexes, where the toxicity is predominantly caused by the abundance of free ions. The toxicity of copper decreased with the addition of humic acid, while the toxicity of zinc remained almost constant. On the other hand, the toxicity of lead increased, depending on the concentration of humic acid. The interactive effects between copper and zinc and between lead and zinc were synergistic, while the interactive effect between copper and lead on the bioluminescence of Vibrio fischeri was additive [13].

\section{CONCLUSIONS}

The study of inhibition of Vibrio fischeri in the municipal waste water implies that the inhibition is primarily affected by the presence of organics and nutrients in water. After degradation of organics (30 days), the value of measured inhibition $(27.67 \%)$ corresponds to the real impact of the pollutants. During 30 days organics degraded and consequently, risk elements combined onto organic complexes must have been released. Organic micropollutants (PAH, hydrocarbons $\mathrm{C}_{10}-\mathrm{C}_{40}$ and tensides, or substances contained in cosmetics) must have been released in a similar manner [14]. The median value for COD of the complete set was $362 \mathrm{mg} / \mathrm{L}$, the median value of COD after 30 days was $174 \mathrm{mg} / \mathrm{L}$, and the degradation efficiency of organics was $52 \%$. The impact of degradation of organics on the increase in ecotoxicity showed in the Martinovsky collector, where the inhibition of Vibrio fischeri after 30 days increased.

\section{ACKNOWLEDGMENT}

This paper was supported by the research projects of the Ministry of Education, Youth and Sport of the Czech Republic: OpVaVpi ENET CZ.1.05/2.1.00/03.0069.

\section{REFERENCES}

[1] M. Farré, L. Kantiani, S. Pérez, and D. Barceló, "Sensors and biosensors in support of EU Directives," Trac-Trends Anal. Chem., vol. 28, pp. 170-185, February 2009.

[2] E. Mendonça, A. Picado, S.M. Paixão, L. Silva, M.A. Cunha, S. Leitão, I. Moura, C. Cortez, and F. Brito, "Ecotoxicity tests in the environmental analysis of wastewater treatment plants: Case study in Portugal," J. Hazard. Mater., vol. 163, pp. 665-670, April 2009.

[3] A.M. Christensen, F. Nakajima, and A. Baun, "Toxicity of water and sediment in a small urban river (Store Vejleå, Denmark)," Environ. Pollut., vol. 144, pp. 621-625, November 2006.

[4] CH.J. Kelly, N. Tumsaroj, and C.A. Lajoie, "Assessing wastewater metal toxicity with bacterial bioluminescence in a bench-scale wastewater treatment system," Water Res., vol. 38, pp. 423-431, January 2004.

[5] H. Raclavská, Š. Doškářová, and H. Škrobánková, "Ecotoxicity of sewage sludge from waste water treatment plant," Inżynieria Mineralna, vol. 27, pp. 39-50, January 2011.

[6] M. Ozaki, M. Suwa, and Y. Suzuki, "Study on risk management of heavy metals for reuse of biosolids," Water Sci. Technol., vol. 53, pp. 189-195, May 2006.

[7] R. Buzier, M.-H. Tusseau-Vuillemin, C.M. dit Meriadec, O. Rousselot, and J.-M. Mouchel, "Trace metal speciation and fluxes within a major French wastewater treatment plant: Impact of the successive treatments stages," Chemosphere, vol. 65, pp. 2419-2426, December 2006.

[8] J. Houhou, B.S. Lartiges, E. Montarges-Pelletier, J. Sieliechi, J. Ghanbaja, and A. Kohler, "Sources, nature, and fate of heavy metalbearing particles in the sewer system," Sci. Total Environ., vol. 407, pp. 6052-6062, November 2009.

[9] A. Katsoyiannis and C. Samara, "Ecotoxicological evaluation of the wastewater treatment process of the sewage treatment plant of Thessaloniki, Greece,” J. Hazard. Mater., vol. 141, pp. 614-621, March 2007.

[10] M. Nohava, R.W. Vogel, and H. Gaugitsch, "Evaluation of the bacteria bioassay for the estimation of the toxicological potential of effluent water samples - Comparison with data from chemical analyses," Environ. Int., vol. 21, pp. 33-37, 1995.

[11] Ch.Y. Hsieh, M.H. Tsai, D.K. Ryan, and O.C. Pancorbo, "Toxicity of the 13 priority pollutant metals to Vibrio fisheri in the Microtox ${ }^{\circledR}$ chronic toxicity test,"Sci. Total Environ., vol. 320, pp. 37-50, March 2004.

[12] E. Fulladosa, J.C. Murat, M. Martínez, and I. Villaescusa, "Patterns of metals and arsenic poisoning in Vibrio fischeri bacteria," Chemosphere, vol. 60, pp. 43-48, June 2005.

[13] V. Tsiridis, M. Petala, P. Samaras, S. Hadjispyrou, G. Sakellaropoulos, and A. Kungolos, "Interactive toxic effects of heavy metals and humic acids on Vibrio fischeri," Ecotox. Environ. Safe., vol. 63, pp. 158-167, January 2006.

[14] S. Girotti, E.N. Ferri, M.G. Fumo, and E. Maiolini, "Monitoring of environmental pollutants by bioluminescent bacteria," Anal. Chim. Acta, vol. 608, pp. 2-29, February 2008.

[15] Environmental Restoration Division, "Aquatic toxicity reference values (TRVs)," U.S.EPA Region 6, Office of solid Wastes e1-e100, ERD-AG003, August 1999.

\section{Creative Commons Attribution License 4.0 (Attribution 4.0 International, CC BY 4.0)}

This article is published under the terms of the Creative Commons Attribution License 4.0

https://creativecommons.org/licenses/by/4.0/deed.en_US 